\title{
Moeite met rondkomen en vitaliteit in Zuid-Holland Zuid
}

\author{
Ester A. L. de Jonge - H. S. (Suzan) Bras · Arne C. Mellaard
}

Published online: 11 March 2020

(c) The Author(s) 2020

\begin{abstract}
Samenvatting
Inleiding Bij lokale overheden groeit het bewustzijn dat armoede samenhangt met stress en een verminderde gezondheid. Vitaliteit is een aspect van gezondheid waar beleidsmakers graag op zouden willen sturen, maar dat niet in alle Nederlandse gemeenten gemeten wordt. We hebben de relatie tussen moeite met rondkomen en vitaliteit in de regio Zuid-Holland Zuid kwantitatief onderzocht, met extra aandacht voor mediatie door angst en depressie.

Methode Voor dit dwarsdoorsnedeonderzoek is gebruikgemaakt van de Gezondheidsmonitor volwassenen en ouderen uit 2016. Deze vragenlijst is ingevuld door een aselecte steekproef van 10.650 volwassen inwoners van Zuid-Holland Zuid. De relatie tussen moeite met rondkomen en vitaliteit is bepaald op basis van lineaire regressiemodellen, gecorrigeerd voor potentiële confounders of verklarende variabelen. Verschillen tussen gemeenten zijn onderzocht met behulp van multilevel-analyses.

Resultaten Inwoners die moeite ervaren met rondkomen waren minder vitaal dan inwoners die geen moeite ervaren met rondkomen, en dit verschil was groter naarmate moeite met rondkomen ernstiger was. Ten opzichte van de groep inwoners die geen moeite ervaart met rondkomen was de vitaliteitsscore $\quad 0,23$ (95\%-betrouwbaarheidsinterval $0,18-0,29)$ punten lager bij weinig moeite, $0,49(95 \%$ BI $0,40-0,57)$ punten bij een beetje moeite en 0,92 (95\%-BI 0,77-1,07) punten lager bij veel moeite met rondkomen, op een schaal van maximaal 7 punten, na correctie voor confounders. De geobserveerde re-
\end{abstract}

E. A. L. de Jonge $(\bowtie) \cdot$ H. S. Bras · A. C. Mellaard

Cluster Regie, Onderzoek en Advies, GGD Zuid-Holland

Zuid, Dordrecht, Nederland

eal.de.jonge@ggdzhz.nl latie werd grotendeels verklaard door verschillen in angst en depressie.

Conclusie Inwoners die moeite ervaren met rondkomen zijn minder vitaal. Hun verhoogde risico op angst en depressie ligt hier mogelijk aan ten grondslag. Vervolgonderzoek is nodig om oorzaak en gevolg verder te ontrafelen. Deze resultaten zijn een reden om de samenwerking tussen verschillende beleidsdomeinen, zoals het sociaal domein en volksgezondheid te versterken.

Trefwoorden moeite met rondkomen - vitaliteit . armoede $\cdot$ stress $\cdot$ gezondheidsbeleid

\section{Financial stress and vitality in the South-West of} the Netherlands
Abstract
Introduction The relation between poverty, stress and impaired health recently gained interest at Dutch lo- cal municipalities. Vitality is an aspect of health which policy makers would like to influence, but is not quan- tified and studied in every Dutch municipality yet. We studied the association between difficulties making ends meet and vitality with a focus on mediation by the risk of anxiety and depression.
Methods This cross-sectional study was performed using data of a local health monitor for adults and elderly (2016). Based on random sampling 10,650 inhabitants aged 19 years and older were included in this study. Associations between difficulties making ends meet and vitality were studied using linear re- gression models, adjusted for potential confounders or mediators. Differences between municipalities were studied using multilevel analyses.
Results People who experienced difficulties making ends meet were less vital than those who did not. Among people who experienced no difficulties mak- 
ing ends meet, the average vitality score was 4.94 (on a 7-point scale). Compared to this reference group, people who experienced a little, some or a lot of difficulties making ends meet had 0.23 (95\%-CI 0.18-0.29), 0.49 (95\%-CI 0.40-0.57) and 0.92 (95\%-CI 0.77-1.07) lower vitality scores, after adjustment for confounders. The observed relationship was largely mediated by the risk of anxiety and depression. No significant differences between municipalities were observed.

Conclusion Financial stress was associated with impaired vitality in Dutch adults. Their increased risk of anxiety and depression might explain this association. More research of longitudinal nature is needed to further unravel causes and consequences. This study underpins the importance of multidisciplinary policy development, for example by intensifying the collaboration between the social domain and public health.

Keywords difficulty making ends meet · vitality · poverty $\cdot$ stress $\cdot$ health policy

\section{Inleiding}

Mede dankzij het boek Schaarste groeit bij lokale overheden het bewustzijn van de relatie tussen armoede en een verminderde gezondheid [1]. Deze relatie is ook in Nederland onderzocht. Zo is bekend dat mensen met financiële stress een grotere kans hebben op overmatig alcoholgebruik, roken, ongezonde voedingskeuzen, een inactieve leefstijl en obesitas [2]. Naast deze traditionele indicatoren van publieke gezondheid is er bij beleidsnetwerken van publieke en private partijen een groeiende interesse in de meer holistische maten van gezondheid, zoals vitaliteit. Voorbeelden van initiatieven die zich richten op vitaliteit zijn De Vitale Revolutie in Zeeland en Vitaal en Veerkrachtig Zuid-Holland Zuid. Dergelijke initiatieven hebben als ambitie een beweging op gang te brengen waarin het accent verlegd wordt van ziekte en zorg naar gezondheid en gedrag [3]. Op deze manier wordt het begrip 'Positieve gezondheid', gedefinieerd als het vermogen van mensen om met de fysieke, emotionele en sociale uitdagingen van het leven om te gaan, geïmplementeerd in beleid [4].

Deze ambities passen in het streven om de verhouding tussen de Nederlandse staat en haar burgers te veranderen, onder andere door het bevorderen van de zelfredzaamheid van inwoners [5]. De Nederlandse Vitaliteitsmeter, de Vita-16, is speciaal ontwikkeld om vitaliteit in de algemene bevolking te meten. Dit in tegenstelling tot eerder ontwikkelde maten, die bijvoorbeeld toegespitst zijn op subpopulaties of een minder brede definitie van vitaliteit beoogden. Op basis van literatuur en de visies van experts zijn drie kerndimensies van vitaliteit gekozen, te weten energie, motivatie en veerkracht. De dimensie energie omvat zowel een fysiek aspect ('zich energiek voelen'), als een mentaal aspect ('afwezigheid van vermoeidheid'). Motivatie omvat doelen stellen in het leven en moeite doen om deze te behalen, waarvan verondersteld wordt dat deze nodig zijn om richting te geven aan het leven. Veerkracht betreft een dynamisch en lerend proces, waarbij mensen herstellen na een ingrijpende gebeurtenis en weer doorgaan met het dagelijkse leven [6]. Op basis van de schaarstetheorie en een recent reviewonderzoek naar de psychische effecten van armoede is onze hypothese dat armoede samenhangt met een verminderde vitaliteit en dat stress deze samenhang mede verklaart $[1,7]$.

Het meetbaar maken en monitoren van de gezondheid op populatieniveau is een wettelijke taak van de gemeentelijke gezondheidsdiensten (GGD-en). Deze taak wordt onder andere uitgevoerd door periodiek vragenlijsten af te nemen bij inwoners vanaf 19 jaar (volwassenen en ouderen). In deze vragenlijst zijn armoede en stress echter niet direct opgenomen, maar wel vragen die deze begrippen benaderen. In dit onderzoek hebben we onze hypothese getoetst op basis van beschikbare lokale gegevens van inwoners van Zuid-Holland Zuid. Een groot deel van deze lokale vragenlijst is ook landelijk gebruikt om de gezondheid van inwoners in andere GGD-regio's te monitoren. De Vita-16 is echter alleen lokaal uitgevraagd. Antwoorden op onze onderzoeksvragen kunnen wellicht bijdragen aan het identificeren van verminderd vitale inwoners in andere gemeenten, ook wanneer vitaliteit als zodanig niet is uitgevraagd. Concreet zijn de volgende onderzoeksvragen geformuleerd:

1. Wat zijn de kenmerken van inwoners die moeite hebben met rondkomen?

2. Hoe sterk is het verband tussen moeite met rondkomen en vitaliteit?

3 . In welke mate wordt dit verband verklaard door verschillen in angst en depressie (als benadering van stress)?

\section{Methode}

\section{Gegevensverzameling en onderzoekspopulatie}

Voor deze analyse is gebruikgemaakt van de Gezondheidsmonitor volwassenen en ouderen van 2016 (GM2016). Op basis van een aselecte steekproef is deze vragenlijst verstuurd naar meer dan 31.000 inwoners van 17 gemeenten in Zuid-Holland Zuid. Dit betreft de gemeenten Dordrecht, Zwijndrecht, HendrikIdo-Ambacht, Alblasserdam, Papendrecht, Sliedrecht, Hardinxveld-Giessendam, Gorinchem, Molenwaard, Giessenlanden, Zederik, Leerdam, Strijen, Cromstrijen, Oud-Beijerland, Binnenmaas en Korendijk (GGD-regio-indeling van 2016). De respons was $28 \%$ onder volwassenen (19-65 jaar) en $49 \%$ onder ouderen (65 jaar en ouder). In totaal zijn 10.650 inwoners geïncludeerd in dit onderzoek. Alle informatie is gebaseerd op zelfrapportage van de inwoners en gepseudonimiseerd. De vragenlijst bevat een begeleidende brief waarin wordt uitgelegd dat de gegevens van deelnemers zullen worden gebruikt voor 
de ontwikkeling van statistieken over de Nederlandse samenleving en dat antwoorden strikt vertrouwelijk worden behandeld en verwerkt.

\section{Het meten van moeite met rondkomen, vitaliteit en het risico op angst en depressie}

De GM2016 bevatte vier vragen over energie, zes over veerkracht en zes over motivatie (bijlage A), die samen de drie kerndimensies van vitaliteit vormen (Vita-16) [6]. De dimensie energie zegt iets over de mate waarin inwoners hun dagelijkse bezigheden kunnen volbrengen met de hoeveelheid energie die ze hebben. De dimensie veerkracht heeft betrekking op de manier waarop mensen omgaan met tegenslagen en andere ervaringen in het leven. De dimensie motivatie zegt iets over de waarde die inwoners hechten aan het maken en realiseren van plannen voor de toekomst. Voor elke vraag kan minimaal een score van 1 (zelden) en maximaal een score van 7 (altijd) worden toegekend. De scores van de verschillende vragen zijn opgeteld en gemiddeld, zowel per dimensie als in de vorm van een totaalscore van vitaliteit. Dit resulteert in scores tussen de 1 en 7, zowel per dimensie als voor het totaal.

Armoede en stress zijn complexe begrippen die niet als zodanig worden gemeten in de GM2016. Daarom is er naar bestaande vragen gezocht die deze twee begrippen benaderen. Voor armoede is gebruikgemaakt van de vraag of mensen moeite ervaren met rondkomen van het huishoudinkomen, waarbij vier antwoordcategorieën mogelijk waren, te weten: 'Nee, geen enkele moeite', 'Nee, geen moeite, maar ik moet wel opletten op mijn uitgaven', 'Ja, enige moeite' en 'Ja, grote moeite'. Als proxy voor stress is gebruikgemaakt van de Kessler Psychological Distress Scale (K10) voor de prevalentieschatting van depressie en angststoornissen (zie bijlage A voor details van de vragen $[8,9])$.

\section{Beschrijvende statistiek}

Het percentage inwoners dat moeite ervaart met rondkomen is weergegeven naar achtergrondkenmerk en gewogen met behulp van factoren die aangeleverd zijn door het Rijkinstituut voor Volksgezondheid \& Milieu (RIVM [10]). Potentiële verschillen zijn met de chikwadraattoets getoetst op statistische significantie.

\section{De relatie tussen moeite met rondkomen en vitaliteit}

De relatie tussen moeite met rondkomen en vitaliteit is bepaald met behulp van lineaire regressieanalyses. Hierbij is moeite met rondkomen in vier categorieën geïncludeerd als onafhankelijke variabele en vitaliteit als afhankelijke variabele met een normale verdeling. Hierbij is de categorie 'geen moeite met rondkomen' als referentiecategorie gekozen. Om te bepalen in welke mate deze relatie verklaard kan worden door potentiële confounders of mediators zijn vier verschillende modellen gebouwd. Er is sprake van confounding wanneer een kenmerk zowel gerelateerd is aan moeite met rondkomen als aan vitaliteit, en daardoor het geobserveerde verband verstoort [11]. Er is sprake van mediatie wanneer het verband tussen moeite met rondkomen en vitaliteit kan worden verklaard door een bepaald kenmerk.

Het eerste model is een basismodel. Het tweede model is gecorrigeerd voor leeftijd, huishoudsamenstelling, burgerlijke staat en opleidingsniveau. Voor huishoudsamenstelling en burgerlijke staat zijn dummy-variabelen aangemaakt, omdat dit nominale variabelen betreft zonder natuurlijke rangorde. Het derde model is gecorrigeerd voor leefstijlfactoren, te weten alcoholconsumptie in glazen per dag, roken (dichotoom) en body mass index (BMI) als indicator van (on)gezond gewicht. De BMI in $\mathrm{kg} / \mathrm{m}^{2}$ is berekend op basis van lengte en gewicht zoals gerapporteerd door de deelnemers zelf.

Tot slot is in het vierde model aanvullend gecorrigeerd voor het risico op een angst- of depressiestoornis (totaalscore). De mate waarin deze potentiële mediator de relatie tussen moeite met rondkomen en vitaliteit verklaart, is vastgesteld op basis van de Sobeltest voor mediatie.

Verschillen tussen gemeenten zijn vervolgens bepaald met behulp van multilevel-analyses [12].

In een sensitiviteitsanalyse is model 3 toegepast met de scores van de verschillende kerndimensies als afhankelijke variabelen, in plaats van de totaalscore. Hiermee wordt duidelijk of de relatie tussen moeite met rondkomen en vitaliteit volledig gedreven wordt door een specifieke kerndimensie, of dat alle dimensies hierin belangrijk zijn. De analyses zijn uitgevoerd met behulp van de statistische softwareprogramma's SPSS (versie 23) en R Studio (versie 1.1.383).

\section{Resultaten}

\section{Welke inwoners ervaren moeite met rondkomen?}

In totaal ervaart $13 \%$ van alle respondenten van de regio Zuid-Holland Zuid moeite met rondkomen. Het grootste deel $(10 \%)$ ervaart enige moeite en slechts een klein deel (3\%) grote moeite. Uit fig. 1 (ongewogen data) blijkt dat moeite met rondkomen vooral wordt ervaren door inwoners die gescheiden zijn of leven, het allerlaagste huishoudinkomen hebben en/of een bijstandsuitkering hebben. Daarnaast zijn deze inwoners vaak arbeidsongeschikt, werkloos, werkzoekend of ze hebben een betaalde baan voor maximaal 12 uur per week. Ook ervaren rokers vaker moeite met rondkomen dan niet-rokers (fig. 1). Deze contrasten tussen groepen zijn vergelijkbaar, maar iets sterker na toepassing van de weegfactoren. Verschillen in moeite met rondkomen tussen verschillende leeftijdsgroepen zijn heel klein. Inwoners van 30-34 jaar (16 \%) en van 
Figuur 1 Demografische kenmerken van inwoners die vaker moeite ervaren met rondkomen (ten opzichte van het onderzoekspopulatiegemiddelde van $13 \%$ aangegeven als stippellijn, ongewogen data)

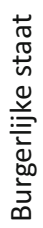

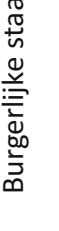

Percentage inwoners dat moeite ervaart met rondkomen

Weduwe/weduwnaar $(n=1211)$ Gescheiden (levend) $(n=705$ ) Nooit gehuwd geweest $(n=914)$ Samenwonend $(n=658)$ Gehuwd/geregistreerd partner $(n=7093)$

Hoog opgeleid $(n=2589)$ Midden opgeleid $(n=3531)$ Laag opgeleid $(n=4583)$

Hoogste inkomen $(n=2851)$ Hoog inkomen $(n=2691)$ Midden inkomen $(n=2220)$ Laag inkomen $(n=2111)$ Laagste inkomen $(n=728)$ Studenten $(\mathrm{n}=341)$ Huisvrouw/-man ( $n=2421)$ Bijstandsuitkering $(\mathrm{n}=141)$

Arbeidsongeschikt ( $n=370$ ) Werkloos/werkzoekend $(n=230)$ Pensioen $(n=3458)$

Betaalde baan, 0-12 uur ( $n=390)$ Betaalde baan, $12-20$ uur ( $n=529$ ) Betaalde baan, 20-32 uur ( $n=1098)$ Betaalde baan, $\geq 32$ uur $(n=2723)$ Geen overgewicht ( $n=4544)$ Overgewicht $(n=5693)$
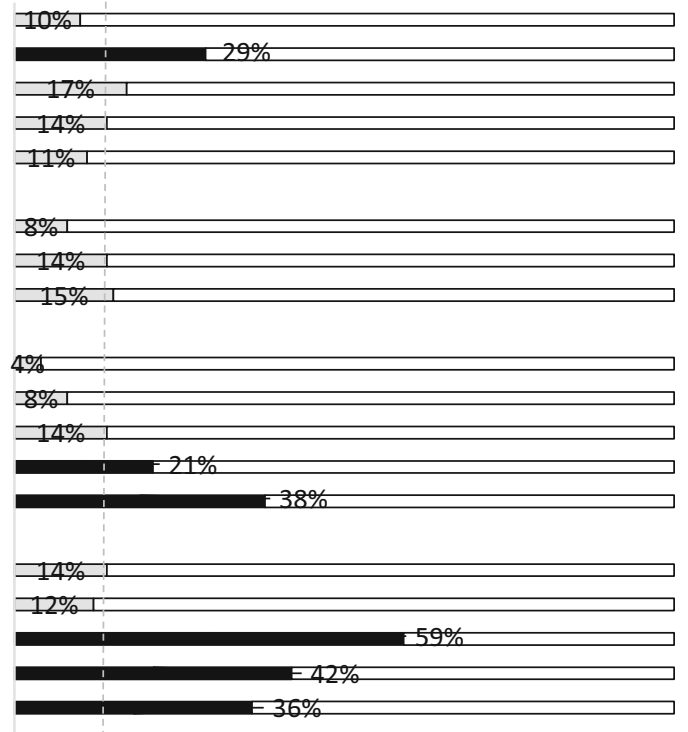

三
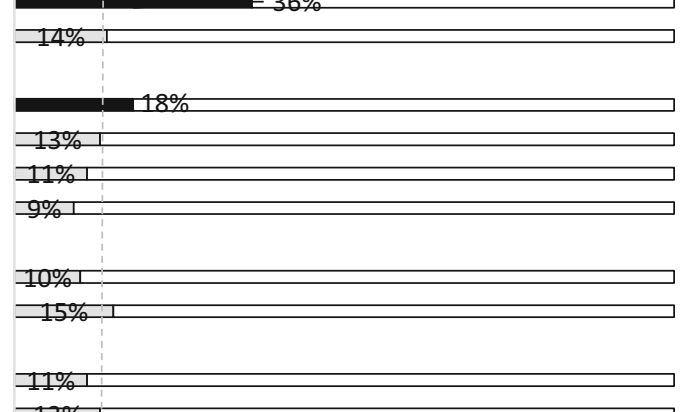

$13 \%$

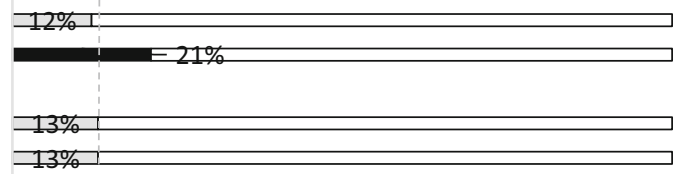

$0 \%$

$20 \% \quad 40 \% \quad 60 \% \quad 80 \% \quad 100 \%$

50-54 jaar (17\%) hebben hier vaker moeite mee dan inwoners in de overige leeftijdsgroepen (10-15\%).

Balkjes in zwart geven de kenmerken aan van subgroepen inwoners die significant $(p<0,05)$ vaker moeite met rondkomen ervaren dan de andere subgroepen binnen dezelfde categorie (bijvoorbeeld mensen die gescheiden zijn of gescheiden leven ten opzichte van alle andere subgroepen in de categorie burgerlijke staat). Aantallen tellen niet altijd precies op tot het totaal van 10.650 respondenten door kleine aantallen ontbrekende waarden (bijvoorbeeld $3 \%$ bij informatie over alcoholgebruik) of doordat een respondent meerdere categorieën kan invullen (bijvoorbeeld bij arbeidsstatus).

\section{Hoe sterk is het verband tussen moeite met rondkomen en vitaliteit?}

Inwoners die moeite met rondkomen ervaren zijn minder vitaal dan inwoners die geen moeite met rondkomen ervaren (tab. 1, model 1). Hoe meer moeite met rondkomen werd ervaren, hoe minder vitaal. Ten opzichte van de groep inwoners die geen moeite ervaren met rondkomen was de vitaliteitsscore $0,40(95 \%-B I 0,34-0,45)$ punten lager bij weinig moeite, 0,76 (95\%-BI 0,68-0,85) punten bij een beetje moeite en 1,40 (95\%-BI 1,29-1,59) punten lager bij veel moeite met rondkomen. De gemiddelde vitaliteitsscore in de referentiecategorie is 4,94. Daarom kan een regressiecoëfficiënt van $-0,40$ worden geïnterpreteerd als een $(0,40 / 4,94 \times 100=) 8 \%$ lagere score ten opzichte van de inwoners die geen moeite ervaren met rondkomen. Dit verschil in vitaliteit wordt voor ruim een derde statistisch significant deel ver- 
Tabel 1 Relatie tussen moeite met rondkomen en vitaliteit

\begin{tabular}{|c|c|c|c|c|c|c|c|c|}
\hline \multirow[t]{2}{*}{$\begin{array}{l}\text { Moeite met } \\
\text { rondkomen? }\end{array}$} & \multicolumn{2}{|c|}{$\begin{array}{l}\text { Model } 1 \\
\text { Basis }\end{array}$} & \multicolumn{2}{|c|}{$\begin{array}{l}\text { Model } 2 \\
\text { Demografie }\end{array}$} & \multicolumn{2}{|c|}{$\begin{array}{l}\text { Model } 3 \\
\text { Leefstijl }\end{array}$} & \multicolumn{2}{|c|}{$\begin{array}{l}\text { Model } 4 \\
\text { Angst en depressie }\end{array}$} \\
\hline & $\beta$ & $95 \%-B I$ & $\beta$ & $95 \%-\mathrm{BI}$ & $\beta$ & $95 \%-B I$ & $\beta$ & $95 \%-B I$ \\
\hline Geen moeite & \multicolumn{2}{|c|}{ Referentie } & \multicolumn{2}{|c|}{ Referentie } & \multicolumn{2}{|c|}{ Referentie } & \multicolumn{2}{|c|}{ Referentie } \\
\hline Weinig & $-0,40$ & $(-0,45$ tot $-0,34)$ & $-0,23$ & $(-0,28$ tot $-0,17)$ & $-0,23$ & $(-0,29$ tot $-0,18)$ & $-0,09$ & $(-0,13$ tot $-0,42)$ \\
\hline Een beetje & $-0,76$ & $(-0,85$ tot $-0,68)$ & $-0,51$ & $(-0,59$ tot $-0,42)$ & $-0,49$ & $(-0,57$ tot $-0,40)$ & $-0,10$ & $(-0,17$ tot $-0,03)$ \\
\hline Veel & $-1,40$ & $(-1,59$ tot $-1,29)$ & $-0,95$ & $(-1,10$ tot $-0,80)$ & $-0,92$ & $(-1,07$ tot $-0,77)$ & $-0,04$ & $(-0,17$ tot 0,08$)$ \\
\hline
\end{tabular}

Tabel 2 Relatie tussen moeite met rondkomen en drie dimensies van vitaliteit: energie, motivatie en veerkracht

\begin{tabular}{|c|c|c|c|c|c|c|}
\hline \multirow[t]{2}{*}{$\begin{array}{l}\text { Moeite met } \\
\text { rondkomen? }\end{array}$} & \multicolumn{2}{|c|}{$\begin{array}{l}\text { Dimensie } \\
\text { Energie }\end{array}$} & \multicolumn{2}{|c|}{$\begin{array}{l}\text { Dimensie } \\
\text { Motivatie }\end{array}$} & \multicolumn{2}{|c|}{$\begin{array}{l}\text { Dimensie } \\
\text { Veerkracht }\end{array}$} \\
\hline & $\beta$ & $95 \%-B I$ & $\beta$ & $95 \%-B \mid$ & $\beta$ & $95 \%-B I$ \\
\hline Geen moeite & \multicolumn{2}{|c|}{ Referentie } & \multicolumn{2}{|c|}{ Referentie } & \multicolumn{2}{|c|}{ Referentie } \\
\hline Weinig & $-0,30$ & $(-0,36$ tot $-0,23)$ & $-0,18$ & $(-0,25$ tot $-0,11)$ & $-0,20$ & $(-0,26$ tot $-0,13)$ \\
\hline Een beetje & $-0,61$ & $(-0,71$ tot $-0,40)$ & $-0,40$ & $(-0,51$ tot $-0,29)$ & $-0,41$ & $(-0,51$ tot $-0,31)$ \\
\hline Veel & $-1,11$ & $(-1,29$ tot $-0,94)$ & $-0,71$ & $(-0,88$ tot $-0,52)$ & $-0,85$ & $(-1,02$ tot $-0,68)$ \\
\hline
\end{tabular}

tekend door verschillen in demografische factoren (tab. 1, model 2) en leefstijlfactoren (tab. 1, model 3) en blijft significant na correctie. Er zijn geen aanwijzingen gevonden dat de relatie tussen gemeenten verschilt. Sensitiviteitsanalyses laten zien dat moeite met rondkomen samenhangt met alle kerndimensies van vitaliteit, na correctie voor confounders. Er zijn echter wel kleine verschillen in de sterkte van het verband. Deze is het sterkst met de dimensie energie, gevolgd door veerkracht en het minst sterk met motivatie (tab. 2).

\section{In welke mate wordt dit verband verklaard door verschillen in angst en depressie?}

Aanvullende correctie voor angst en depressies zorgt ervoor dat de relatie sterk afzwakt.

Voor de mensen die veel moeite ervaren met rondkomen, verklaren angst en depressie zelfs de hele relatie (tab. 1, model 4). Dit suggereert dat mensen die (veel) moeite met rondkomen ervaren hoger scoren op de angst- en depressievragenlijst, en daardoor minder vitaal zijn dan mensen die geen moeite ervaren met rondkomen. De mediatieanalyse laat zien dat het directe effect van moeite met rondkomen op vitaliteit $-0,06$ is, terwijl het indirecte effect via angst en depressie $-0,23$ is (details in bijlage $B$ ).

\section{Beschouwing}

\section{Kenmerken van inwoners die moeite hebben met rondkomen}

In dit onderzoek werd moeite met rondkomen vooral ervaren door inwoners die gescheiden zijn of leven, die het allerlaagste huishoudinkomen hebben en/of een bijstandsuitkering hebben. Hun arbeidsstatus was vaak arbeidsongeschikt, werkloos, werkzoekend of werkend voor maximaal 12 uur per week. Van mensen met een betaalde baan die toch in armoede leven, ook wel 'werkende armen' genoemd, is bekend dat zij vaak zelfstandige zonder personeel (zzp'er) of oproepkracht zijn [13]. Ook beschrijft bestaande literatuur kenmerken van mensen in armoede die moeilijker te meten zijn met vragenlijstonderzoek, zoals laaggeletterdheid, of niet zijn opgenomen in onze vragenlijst, zoals het wonen in een huurwoning $[14,15]$.

\section{Relatie met de schaarstetheorie}

Inwoners van Zuid-Holland Zuid die moeite ervaren met rondkomen waren minder vitaal dan inwoners die geen moeite met rondkomen ervaren. Hoe meer moeite met rondkomen mensen ervaarden, hoe minder vitaal ze waren. Deze relatie werd grotendeels verklaard door verschillen in hun risico op angst en depressies. Volgens de schaarstetheorie worden mensen met financiële stress, vooral wanneer dit lang aanhoudt, blootgesteld aan chronische stress [1]. Deze stress kan directe gevolgen hebben voor de (mentale) gezondheid, maar kan er ook indirect voor zorgen dat 
mensen ongezondere keuzen maken en daardoor inleveren op hun gezondheid [16]. Een mogelijke verklaring hiervoor is dat de chronische stressvolle omstandigheden veranderingen in de hersenen veroorzaken, waardoor mensen zich meer gaan focussen op overleven in het hier en nu en minder op de toekomst. Dit onderzoek vormt een aanvulling op de beschikbare literatuur over sociaaleconomische gezondheidsverschillen en gedrag, omdat de focus vooral op vitaliteit ligt en niet zozeer op onderdelen van leefstijl of specifieke aspecten van de fysieke of mentale gezondheid $[17,18]$. Het gebruik van de Vita-16-vragenlijst kan worden beschouwd als een manier om sociaaleconomische verschillen in Positieve Gezondheid meetbaar te maken op populatieniveau [6].

\section{Methodologische uitdagingen}

In dit onderzoek waren geen objectieve gegevens beschikbaar over het chronischestressniveau van de inwoners, bijvoorbeeld door middel van een cortisolbepaling via het haar [19]. Daarom is het risico op angst en depressies gebruikt als benadering voor stressniveaus. Het is aangetoond dat de comorbiditeit van angst en depressie samenhangt met verhoogde cortisolniveaus - een weerspiegeling van chronische stress [20]. De K10 is een betrouwbaar instrument voor het vaststellen van angst- en depressiestoornissen. Om de betrouwbaarheid specifiek voor angststoornissen verder te optimaliseren, zou in de toekomst de 'extended' K-10 kunnen worden toegepast [21]. Bedenk echter dat deze vragenlijst vijf extra vragen bevat en dat de lengte van de vragenlijst van invloed kan zijn op het responspercentage. Daarnaast gaat het hier om een dwarsdoorsnedeonderzoek. Dat wil zeggen dat moeite met rondkomen, het risico op angst en depressie, en vitaliteit allemaal op hetzelfde moment bepaald zijn. Het is daarom niet mogelijk om met zekerheid te onderscheiden wat oorzaak is geweest en wat gevolg. Met deze gegevens kan enkel bewezen worden dat er sprake is van een negatief verband tussen moeite met rondkomen en vitaliteit. We kunnen niet uitsluiten dat de relatie twee kanten op werkt. Onvoldoende energie, veerkracht en motivatie kunnen bijvoorbeeld bijdragen aan baanonzekerheid en daarmee samenhangende financiële stress. Een vervolgonderzoek zou longitudinaal van aard moeten zijn, dat wil zeggen dat dezelfde inwoners op meerdere momenten een vragenlijst invullen. Op deze manier kan worden nagegaan of een verandering in moeite met rondkomen over de tijd samengaat met een verandering in de vitaliteit. Dit zou een eerste, realistische stap zijn in het onderbouwen van causaliteit.

\section{Selectieve respons en het risico op selectiebias}

Inwoners met het laagste huishoudinkomen (bijlage C) waren ondervertegenwoordigd in dit onderzoek. Ook uit andere onderzoeken is bekend dat personen met een minder gunstige maatschappelijke positie vaak ondervertegenwoordigd zijn, bijvoorbeeld in enquêtes van het CBS [11]. Inwoners kunnen verschillende redenen hebben om niet mee te doen aan vragenlijstonderzoek. Vertrouwen in de betreffende organisatie of in onderzoek in algemene zin kan hieraan bijdragen. Daarnaast kunnen eerdere ervaringen met vragenlijstonderzoek en interesse in het onderwerp gezondheid de bereidheid om mee te werken beïnvloeden en kan laaggeletterdheid deelname belemmeren [22]. Deze selectieve respons hoeft echter niet altijd tot selectiebias te leiden. Er is pas sprake van selectiebias als de non-respons samenhangt met de uitkomst, vitaliteit, én als deze verschilt tussen de te vergelijken groepen wat betreft 'moeite hebben met rondkomen' [23].

Aangenomen dat respondenten waarschijnlijk meer interesse hebben in gezondheid in algemene zin dan de non-respondenten, bestaat de mogelijkheid dat de respondenten ook iets vitaler zijn. Of de non-respons verschillend is tussen inwoners die in verschillende mate moeite met rondkomen ervaren is niet zeker. De ondervertegenwoordiging van inwoners met het laagste huishoudinkomen zou er echter op kunnen wijzen dat de non-respons hoger is onder inwoners die, mede door hun lage inkomen, moeite ervaren met rondkomen. Daarom zou de relatie die in dit onderzoek is gevonden een onderschatting van het werkelijke effect kunnen zijn.

\section{Implicaties voor beleid en aanbevelingen voor vervolgonderzoek}

Op basis van dit onderzoek kunnen verschillende aanbevelingen voor beleid en vervolgonderzoek worden geformuleerd. De samenhang tussen moeite met rondkomen en vitaliteit is een reden om de samenwerking tussen verschillende beleidsdomeinen, zoals het sociaal domein en de publieke gezondheid, te versterken. Beleidsmakers en andere professionals zouden moeten investeren in het begrijpen en aanpakken van de onderliggende oorzaken van verminderde vitaliteit. Wanneer klachten van verminderde vitaliteit samenhangen met financiële druk of onzekerheid zou sociaal beleid zich kunnen richten op het verminderen van stress, angst en depressie. Een eerste stap om stress te helpen reduceren zou kunnen bestaan uit het creëren van orde en overzicht, bijvoorbeeld door de aanvraagprocedure van toeslagen waar een inwoner recht op heeft te vereenvoudigen.

Door middel van kwalitatief onderzoek samen met de inwoners zelf kan nog gerichter worden onderzocht welke overheidsmaatregelen deze doelgroep ondersteuning kunnen bieden om vitaal te blijven. Hierbij dient ook aandacht te zijn voor subgroepen die wij in deze kwantitatieve analyse niet hebben kunnen onderzoeken, zoals inwoners met specifieke culturele achtergronden of overtuigingen. 


\section{Wetenschappelifk artikel}

\section{Bijlage A}

Tabel A.1 Vragenlijst vitaliteit

\begin{tabular}{|c|c|c|c|c|c|c|c|}
\hline & Zelden & Soms & Af en toe & Regelmatig & Meestal & Bijna altijd & Altijd \\
\hline \multicolumn{8}{|l|}{ Energie } \\
\hline \multicolumn{8}{|l|}{$\begin{array}{l}\text { Ik heb genoeg energie om al mijn dagelijkse activitei- } \\
\text { ten te kunnen volbrengen }\end{array}$} \\
\hline \multicolumn{8}{|l|}{ Ik bruis van de energie } \\
\hline \multicolumn{8}{|l|}{$\begin{array}{l}\text { Mijn batterij is } 100 \% \text { opgeladen aan het begin van de } \\
\text { dag }\end{array}$} \\
\hline \multicolumn{8}{|l|}{ Na het avondeten zit ik nog vol energie } \\
\hline \multicolumn{8}{|l|}{ Veerkracht } \\
\hline \multicolumn{8}{|l|}{ Ik ga meteen aan de slag met nieuwe uitdagingen } \\
\hline \multicolumn{8}{|l|}{ Ik kan heel goed omgaan met tegenslagen } \\
\hline \multicolumn{8}{|l|}{$\begin{array}{l}\text { Ik kan heel goed oplossingen vinden in moeilijke situa- } \\
\text { ties }\end{array}$} \\
\hline \multicolumn{8}{|l|}{ Na een moeilijke periode ben ik snel weer de oude } \\
\hline \multicolumn{8}{|l|}{ Door mijn ervaring voel ik mij sterker in moeilijke tijden } \\
\hline \multicolumn{8}{|l|}{ Elke ervaring in het leven maakt mij sterker } \\
\hline \multicolumn{8}{|l|}{ Motivatie } \\
\hline \multicolumn{8}{|l|}{ Ik verheug mij op elke nieuwe dag } \\
\hline \multicolumn{8}{|l|}{ Ik maak plannen voor de toekomst } \\
\hline \multicolumn{8}{|l|}{$\begin{array}{l}\text { Als ik een doel heb, maak ik direct plannen om dit doel } \\
\text { te bereiken }\end{array}$} \\
\hline \multicolumn{8}{|l|}{ Het behalen van mijn doelen maakt mij gelukkig } \\
\hline \multicolumn{8}{|l|}{ Ik krijg energie van het maken van toekomstplannen } \\
\hline $\begin{array}{l}\text { Ik vind het heel erg belangrijk om mijn doelen werke- } \\
\text { lijkheid te laten worden }\end{array}$ & & & & & & & \\
\hline
\end{tabular}

Tabel A.2 Vragenlijst angst- en depressiescore

\begin{tabular}{|c|c|c|c|c|c|}
\hline Onderstaande vragen hebben betrekking op de afgelopen vier weken & Altijd & Meestal & Soms & Af en toe & Nooit \\
\hline \multicolumn{6}{|l|}{ Hoe vaak voelde u zich vermoeid zonder duidelijke reden? } \\
\hline \multicolumn{6}{|l|}{ Hoe vaak voelde u zich zenuwachtig? } \\
\hline \multicolumn{6}{|l|}{ Hoe vaak was u zo zenuwachtig dat u niet tot rust kon komen? } \\
\hline \multicolumn{6}{|l|}{ Hoe vaak voelde u zich hopeloos? } \\
\hline \multicolumn{6}{|l|}{ Hoe vaak voelde u zich rusteloos of ongedurig? } \\
\hline \multicolumn{6}{|l|}{ Hoe vaak voelde u zich zo rusteloos dat u niet meer stil kon zitten? } \\
\hline \multicolumn{6}{|l|}{ Hoe vaak voelde u zich somber of depressief? } \\
\hline \multicolumn{6}{|l|}{ Hoe vaak had u het gevoel dat alles veel moeite kostte? } \\
\hline Hoe vaak voelde u zich zo somber dat niets hielp op u op te vrolijken? & & & & & \\
\hline Hoe vaak vond u zichzelf afkeurenswaardig, minderwaardig of waardeloos? & & & & & \\
\hline
\end{tabular}




\section{Bijlage B}

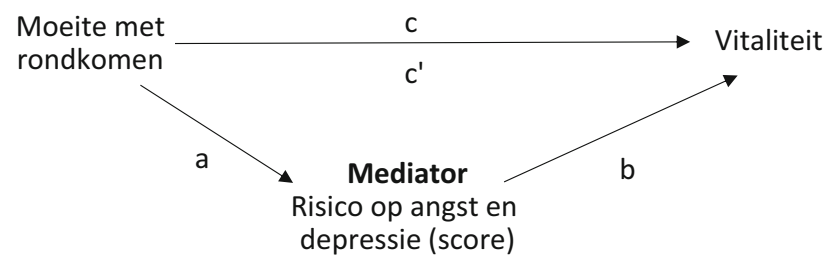

Figuur B.1 Toelichting op effectmediatie door het risico op angst- en depressiestoornissen

Tabel B.1 Interpretatie coëfficiënten

\begin{tabular}{|l|l|l|l|}
\hline Wat? & Welke groepen? & Rekening houdend met? \\
\hline c $^{\prime}$ & Verschil in de vitaliteitsscore & $\begin{array}{l}\text { Inwoners met één categorie verschil in } \\
\text { moeite met rondkomen }\end{array}$ & $\begin{array}{l}\text { Wanneer geen rekening wordt gehouden met het risico op angst en } \\
\text { depressie, en wel met confounders }\end{array}$ \\
\hline a & $\begin{array}{l}\text { Verschil in de vitaliteitsscore } \\
\text { pressiescore }\end{array}$ & $\begin{array}{l}\text { Inwoners met één categorie verschil in } \\
\text { moeite met rondkomen }\end{array}$ & $\begin{array}{l}\text { Wanneer wél rekening wordt gehouden met het risico op angst en } \\
\text { depressie, en ook met confounders }\end{array}$ \\
\hline b & Verschil in de vitaliteitsscore & $\begin{array}{l}\text { Inwoners met een punt verschil in angst- en } \\
\text { depressiescore }\end{array}$ & $\begin{array}{l}\text { Wanneer rekening wordt gehouden met confounders en moeite met } \\
\text { rondkomen }\end{array}$ \\
\hline
\end{tabular}

Tabel B.2 Resultaten [24]

\begin{tabular}{|c|c|c|}
\hline & Schatting & $95 \%$-betrouwbaarheidsinterval \\
\hline C & $-0,29$ & $-0,29$ tot $-0,28$ \\
\hline$c^{\prime}$ & $-0,06$ & $-0,06$ tot $-0,05$ \\
\hline a & 1,97 & 1,94 tot 2,00 \\
\hline b & $-0,12$ & $-0,12$ tot $-0,12$ \\
\hline \multicolumn{3}{|c|}{$\begin{array}{l}\text { Totaal effect }(c)=\text { indirect effect }(a \times b)+\text { direct effect }\left(c^{\prime}\right) \\
\text { Direct effect van moeite met rondkomen op vitaliteit }=-0,06 \\
\text { Indirect effect van moeite met rondkomen op vitaliteit (via angst en } \\
\text { depressie })=(1,97 \times-0,12)=-0,23 \\
\text { Totaal effect }=-0,23+(-0,06)=-0,29 \\
\text { Verklaarde variantie in vitaliteit verklaard door moeite met rondkomen plus } \\
\text { confounders }=19 \% \\
\text { Verklaarde variantie in vitaliteit verklaard door moeite met rondkomen, en } \\
\text { de angst- en depressiescore plus confounders }=47 \% \\
\text { Voor bovenstaande analyse is moeite met rondkomen meegenomen als } \\
\text { continue variabele. }\end{array}$} \\
\hline
\end{tabular}




\section{Bijlage C}

\section{Verkenning van selectieve respons}

\section{Reden en methode van de verkenning}

Uit vragenlijstonderzoek dat in het verleden heeft plaatsgevonden is bekend dat inwoners met een hogere sociaaleconomische status (SES) of positie vaker meedoen met een dergelijk onderzoek dan inwoners met een lagere SES. Huishoudinkomen is een belangrijke indicator van SES. Het huishoudinkomen is op basis van landelijke gegevens ingedeeld in vijf groepen van gelijke grootte (kwintielen van elk $20 \%$ ), met afkapwaarden van maximaal 16.100 (Q1), 21.300 (Q2), 27.200 (Q3) en 35.100 (Q4) en meer dan 35.100 (Q5) euro per jaar. Open source-data van het Centraal Bureau van de Statistiek (CBS) [9] zijn gebruikt om te bepalen welk percentage van alle inwoners van ZuidHolland Zuid binnen deze inkomensgrenzen valt. De inwoners van Zuid-Holland Zuid kunnen worden beschouwd als de bronpopulatie van dit onderzoek. Vervolgens is gekeken welk percentage van alle deelnemers aan ons onderzoek (de onderzoekspopulatie) binnen deze inkomensgrenzen vallen.

\section{Resultaten van de verkenning}

Op basis van fig. C.1 kan worden geconcludeerd dat in de regio Zuid-Holland Zuid iets minder inwoners zijn met het allerlaagste huishoudinkomen (Q1) dan landelijk (15\% versus $20 \%$ ). Het aantal inwoners met dit laagste huishoudinkomen in ons onderzoek was ondervertegenwoordigd (7 \%), terwijl de groep inwoners met het hoogste huishoudinkomen (Q5) juist oververtegenwoordigd was.

Open Access This article is licensed under a Creative Commons Attribution 4.0 International License, which permits use, sharing, adaptation, distribution and reproduction in any medium or format, as long as you give appropriate credit to the original author(s) and the source, provide a link to the Creative Commons licence, and indicate if changes were made. The images or other third party material in this article are included in the article's Creative Commons licence, unless indicated otherwise in a credit line to the material. If material is not included in the article's Creative Commons licence and your intended use is not permitted by statutory regulation or exceeds the permitted use, you will need to obtain permission directly from the copyright holder. To view a copy of this licence, visit http://creativecommons.org/licenses/by/4.0/.
Figuur C.1 Verkenning van de mate waarin de deelnemers van ons onderzoek (de onderzoekspopulatie) een representatieve afspiegeling zijn van de totale Zuid-Hollandse populatie (de bronpopulatie) en van de totale populatie van $\mathrm{Ne}$ derland, op basis van hun inkomen

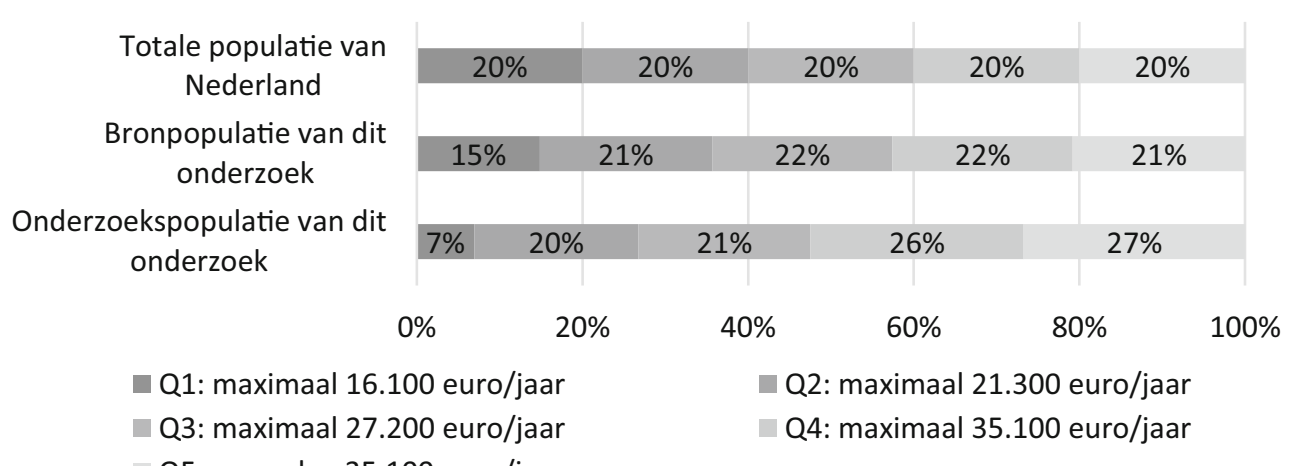

Q5: meer dan 35.100 euro/jaar 


\section{Literatuur}

1. Mullainathan S, Shafir E. Schaarste. Amsterdam: Maven Publishing; 2013.

2. Erasmus MC, Zon MW. Factsheet GLOBE-onderzoek. Rotterdam: Erasmus MC; 2018. www.globe-study.nl/wpcontent/uploads/2018/04/p011712_globe_factsheet_kb_ v6_spreads.pdf.

3. Netwerk Alles is gezondheid. Regionetwerken. Utrecht: NetwerkAlles is gezondheid;2019. www.allesisgezondheid. $\mathrm{nl} /$ netwerk-en-partners/regionetwerken/.

4. Huber M, Knottnerus JA, Green L, et al. How should we definehealth? BMJ.2011;343:d4163.

5. Bredewold F, DuyvendakJW, Kampen T, et al. De verhuizing van de verzorgingsstaat. Hoe de overheid nabij komt. Amsterdam: Van Gennep; 2018.

6. Strijk JE, Wendel-Vos GCW, Picavet HSJ, et al. Wat is vitaliteit en hoe is het te meten? Tijdschr Gezondheidswet. 2015;93(1):32-40.

7. Haushofer J, Fehr E. On the psychology of poverty. Science. 2014;344(6186):862-7.

8. Andrews G, Slade T. Interpreting scores on the Kessler Psychological Distress Scale (K10). Aust NZJ Public Health. 2001;25(6):494-7.

9. Kessler RC, Andrews G, Colpe L, et al. Short screening scales to monitor population prevalences and trends in non-specific psychological distress. Psychol Med. 2002;32(6):959-76.

10. Weging BB. Gezondheidsmonitor 2016. Den Haag: Centraal Bureau voor de Statistiek(CBS); 2017.

11. Riele $S$ te. Vertekening door non-respons: hoe nauwkeurig zijn de uitkomsten van persoonsenquêtes? Den Haag: Centraal Bureau voor de Statistiek (CBS);2002.

12. TwiskJ.Appliedmultilevelanalysis. Cambridge: Cambridge UniversityPress; 2006.
13. Vrooman C, Josten E, HoffS, et al. Als werk weinig opbrengt. Den Haag: Sociaal en Cultureel Planbureau (SCP);2018.

14. Christoffels I, Baay P, Bijlsma, et al. Over de relatie tussen laaggeletterdheid en armoede. 's-Hertogenbosch: Expertisecentrum Beroepsonderwijs; 2016.

15. Schors A van der, Crijnen C, Schonewille G. Geldzaken in de praktijk 2018-2019. Utrecht: Nationaal Instituut voor budgetvoorlichting (NIBUD); 2019.

16. McEwen BS. Neurobiological and systemic effects of chronic stress. Thousand Oaks: Chronic Stress; 2017.

17. OudeGroenigerJ,KamphuisCB, MackenbachJP, etal. Repeatedly measured material and behavioral factors changed the explanation of socioeconomic inequalities in all-cause mortality. JClin Epidemiol. 2017;91:137-45.

18. Petrovic D, Mestral C de, Bochud M, et al. The contribution of health behaviors to socioeconomicinequalitiesinhealth: a systematic review. Prev Med. 2018;113:15-31.

19. Wester VL, Rossum EF van. Clinical applications of cortisol measurements in hair. Eur J Endocrinol. 2015;173(4):M1-10.

20. Gerritsen L, Staufenbiel SM, Penninx B, et al. Long-term glucocorticoid levels measured in hair in patients with depressive and anxiety disorders. Psychoneuroendocrinology. 2019;101:246-52.

21. Donker T, Comijs H, Cuijpers P, et al. The validity of the Dutch K10 and extended K10 screening scales for depressive and anxiety disorders. Psychiatry Res. 2010;176(1):45-50.

22. Rindfuss RR, Choe MK, Tsuya NO, et al. Do low survey response rates bias results? Evidence from Japan. Demogr Res. 2015;32:797-828.

23. Rothman KJ. Epidemiology: an introduction. New York: Oxford University Press; 2012. pag. 96-8.

24. Preacher KJ, Kelly K. Effect size measures for mediation models: quantitative strategies for communicating indirect effects. Psychol Methods. 2011;16(2):93-115. 